\title{
TAKING PAUL SERIOUSLY
}

\section{James A Metzger \\ East Carolina University}

\begin{abstract}
This article explores what it might mean to take Paul seriously about the 'revelatory foundations 'of Christianity. ${ }^{\text {I I }}$ argue that the apostle, unlike most Christian philosophers and theologians today, shows little interest in defending the respectability or reasonableness of Christian belief, whether to insiders or to outsiders. Indeed, Paul concedes that his 'message about the cross' will inevitably seem-and remain - utter 'foolishness' to the overwhelming majority who learn of it (1 Cor 1:18-25). Moreover, because the gospel cannot be inferred from a common body of knowledge or derived with principles of logic, believers have little choice but to trust that Paul has, in fact, received communication from a sacred realm and relayed the message accurately. In an age when evidence and good reasons are (rightly) sought for our models of reality, conceding that the whole edifice rests on the purported veridicality of the visionary experiences of a handful of ancient witnesses, whose credibility we are not well-positioned to assess, necessarily comes with some epistemic embarrassment. But this is the price any Christian who is honest about the origins of her tradition must pay. Unlike the teachings of, say, Confucius or Buddha, most of which have their basis in trial-and-error and rational inquiry, the Christian gospel does not. Paul is not ashamed to admit this. I suggest that those who see Paul as an authority ought to as well.
\end{abstract}

\section{Key Words: Paul; Faith; Divine Revelation; Religious Experience}

Most Christians I know value evidence and critical inquiry and therefore wish to maintain that they are justified holding the beliefs they do about a sacred order. The same, of course, can be said of the most prolific Christian philosophers of our generation: Alvin Plantinga, William Alston and Richard Swinburne, for instance, have devoted a good part of their careers to defending a Christian's 'right to believe' in unseen agents and miraculous events not amenable to ordinary procedures of verification. Plantinga argues that a Christian is fully entitled to include belief in God among other 'properly basic beliefs' for which rational justification is not normally required, as long as her cognitive faculties are working as they should and aimed at generating an accurate picture of reality. ${ }^{2}$ Alston maintains that a person of faith is permitted to treat non-sensory mystical experience that results from well-established doxastic practices much as we treat perceptual experience. So, just as we are (ordinarily) willing to trust the output of our perceptual experience, a Christian should have the right to trust the output of her religious experience, assuming that there are no compelling reasons for its non-veridicality, and that it is more or less consistent with prior

The phrase is borrowed from M Darrol Bryant, 'On Divine Self Disclosure,' Dialogue and Alliance 25.2, 2011:26.

2 Examples of properly basic beliefs - those that are not derived or inferred from other beliefs yet are justifiably held - might include the conviction that one had breakfast this morning or that one is now looking at a pine tree from the kitchen window. See, for instance, his concise (and now widely anthologized) essay 'Is Belief in God Properly Basic?’ Noûs 15.1, 1981:41-51. 
reports about God's nature and intentions. In many cases, observes Alston, we are unable to verify or 'cross-check' other kinds of introspective reports about, say, an individual's level of pain or anxiety, that we nevertheless are inclined to trust, so why automatically dismiss introspective reports about an experience of God simply because we lack testimony from corroborating witnesses? ${ }^{3}$ Finally, Swinburne challenges us both to abandon our longstanding bias against the credibility of ancient witnesses and to consider how miraculous claims such as Jesus' resurrection or the virgin birth might be rational to hold. ${ }^{4}$ Identifying as a Christian in the modern era, they all argue, is a perfectly reasonable thing to do. Even confessing a traditional creed ought to involve no intellectual embarrassment whatever.

But what might Paul think of this inclination to shore up the intellectual respectability of believing in the early Christian message? Might this 'apostle to the Gentiles' join today's Christian philosophers in defending the rationality of committing oneself to the divinely revealed 'mystery' at the heart of the kerygma? Our evidence, admittedly, is limited, for only some of Paul's letters remain, ${ }^{5}$ and we have no correspondence at all from the final few years of his ministry. The general consensus among biblical scholars today is that Paul's seven so-called undisputed letters -1 Thessalonians, $1 \& 2$ Corinthians, Philippians, Galatians, Philemon, and Romans -were all composed during the 50s CE, perhaps within the span of just six or seven years. Because we can observe Paul's thought evolve even within what letters do remain, and because he believed that the Spirit continued to speak through prophecy and glossolalia (1 Cor 14), we have to allow that his understanding of the gospel continued to evolve during the final years of his life - which, if we are to trust the author of Luke-Acts, were probably spent under house arrest in Rome (Acts 28:16;30-31). So, although we do not have access to any changes in how he understood the gospel after he completed his letter (via dictation) to the churches in Rome, enough still remains, I think, to venture a tentative response to the questions posed above.

Based on his seven extant undisputed letters, I will suggest that Paul would find much of today's apologetically driven philosophy of religion both unnecessary and irrelevant. Time, for him, would be spent far better preparing oneself for the imminent return of Jesus ${ }^{6}$ rather than crafting sophisticated arguments for why subscribing to the early Christian message is a perfectly rational option that lies well within one's epistemic rights. Paul, in fact, openly acknowledges that his 'message about the cross' will seem - and remain - utter 'foolishness' to the overwhelming majority who hear about it (1 Cor 1:18-25). He concedes that if his gospel were to be subjected to the canons of reason endorsed by Rome's educated elite (and even by many ordinary citizens of the empire), it very likely would be declared utterly preposterous, beyond the bounds of what one might reasonably believe. But Paul isn't concerned with establishing a far-reaching intellectual respectability of the kind many

3 In fact, says Alston, if a Christian should discover that her mystical practices over time generate significant 'self support' - inner peace, patience, fortitude, love for one's neighbour (and even for one's enemies) - she ought to be granted even further license to trust her perception that it is God who visits and sustains her. For a concise overview, see 'The autonomy of religious experience,' Philosophy of Religion 31, 1992:67-87;

'Religious Experience and Religious Belief,' Noûs 16, 1982:3-12. For a fuller treatment, see Perceiving God: The Epistemology of Religious Experience. Ithaca, NY: Cornell University Press, 1993.

$4 \quad$ I have in mind here Swinburne's now widely cited 'principle of credulity.' His book The Resurrection of God Incarnate. Oxford: Oxford University Press, 2003, offers readers an excellent example of a defense of the rationality of one miraculous claim in particular. See also the short summary in Rolfe King, 'Divine Revelation,' Philosophy Compass 7.7, 2012:498-500.

See, e.g. 1 Cor 5:9.

6 Paul seems to have expected that Jesus would return during his lifetime, at least during the span of time encompassed by his undisputed letters (see especially 1 Thess 4:13-18 and Rom 13:11-14). 
Christian philosophers seek today. Should the content of this recent disclosure strike someone as improbable, just plain bizarre, or even incompatible with certain non-negotiable claims that lie at the heart of the Jewish tradition, then so be it. God's ways, he might reply, are not our ways, and we are in no position to argue with God as to how he goes about extending the gift of eternal life, or even to whom he chooses to extend this offer (see especially Rom 9-11).

Moreover, because Paul's gospel cannot be inferred from a common body of knowledge or derived with principles of logic, potential converts will find themselves in an epistemically awkward - and, at least to my mind, unenviable - position: they will have no choice but to trust that this travelling missionary has, in fact, received communication from a sacred realm and relayed the message accurately. In effect, because Paul's gospel rests entirely on divine revelation, and not on any observable 'facts' that may be verified independently, anyone who is considering joining one of his communities must venture a leap of faith. A potential convert, in other words, will initially find herself in a position of total epistemic dependence.

In an age when empirical evidence and good reasons are routinely sought for our models of reality, conceding that the edifice of early Christianity rests on the purported veridicality of the visionary experiences of a handful of ancient witnesses such as Paul, whose character and credibility we are not well-positioned to assess, necessarily comes with some epistemic embarrassment. But this is the price any Christian who is honest about the origins of her tradition must pay. Unlike the teachings of, say, Confucius or Buddha, many of which have their basis in trial-and-error and rational inquiry, the Christian gospel does not. Paul is not ashamed to admit this. I will suggest that he, unlike many Christian philosophers of religion today, would not bother defending the intellectual respectability or rationality of committing oneself to its core claims. Paul is absolutely convinced that he is a recipient of a message from God, and whether this message proves attractive, plausible, or compatible with certain prior disclosures within the Jewish tradition is of little concern. The message is true because of where it came from, not because it can be verified using existing canons of reason, or because it possesses some innate rationality of its own.

\section{Paul and the Primacy of Divine Revelation}

While Paul seems to have held that anyone should be able to infer that a single deity presides over the cosmos and makes basic moral demands of us (Rom 1:19-21; cf. Wisdom 13:1-9), ${ }^{7}$ he also acknowledges that the specifics of the Christian gospel are inaccessible to empirical observation or rational inquiry. The gospel is a divinely revealed 'mystery' that was concealed from human beings until early in the first century CE, (Rom 16:25-26; 1 Cor $2: 1 ; 4: 1$ ), when God finally elected to make it known to a handful of (male) individuals, who then were commissioned to go out and disseminate the message widely before the consummation of this age. The heart of this mystery involves a new and efficient means to atone for human sin: God's only son was to be "put on public display as a propitiatory

In the Corinthian correspondence, Paul admittedly suggests that no one is able arrive at a knowledge of God 'through [human] wisdom' (1 Cor 1:21), but the statement here is a bit too terse to do much with, and it presumably comes from an earlier stage in his ministry. For the sake of simplicity, I defer to the 'later Paul' of Romans, where there is far less ambiguity. Indeed, it is hard not to concede that he, like other educated Jews of his time, endorses a kind of rudimentary natural theology. 
sacrifice" (Rom 3:25) so that all people - Jews and Gentiles alike - might be "rescued from [God's] coming wrath" (1 Thess 1:10) and "set free from the present evil age" (Gal 1:4).

So, while evidence of the existence of a creator ought to be readily apparent to all, no one is capable of discerning the contents of the gospel without divine intervention. The gospel cannot be inferred from shared truths or arrived at by the principles of logic. In fact, without the illumination of God's Spirit, Paul concedes that the gospel he proclaims will make little if any sense. It comes as a 'stumbling block' (1 Cor 1:23) to Jews who believe that the rites performed at the temple in Jerusalem already atone for sin, and who have no (obvious) precedent in their tradition for a messiah who does nothing whatsoever to expel the reigning imperial power and establish an independent, prosperous kingdom of Israel. And for Gentiles who have no reason to hold the Jewish scriptures authoritative, or who know virtually nothing about Jewish atonement rites, it is all just so much 'foolishness' (1 Cor 1:18-25). But regardless of how strange the gospel may seem, says Paul, it does in fact offer us an accurate account of how God has chosen to work in these last days. The atoning sacrifice of God's son on a Roman cross is now the only means of salvation available to human beings. All other paths to salvation and all prior philosophical speculation - mere 'human wisdom,' according to Paul (1 Cor 2:5,13) - are now rendered obsolete.

The foundation, therefore, of Paul's gospel is divine revelation: had God not chosen to disclose this mystery to us, it would have remained entirely inaccessible. Indeed, when writing to the churches in Galatia, Paul makes a point of saying that he did not receive his gospel from a 'human source' but from a 'revelation of Jesus Christ, ${ }^{, 10}$ whom "God was pleased to reveal ... in [him]" (1:11-17). But, can Paul really mean that his entire gospel was revealed? Given his former involvement in persecuting the church (Gal 1:13-14), he must already have been well-acquainted not only with what Christians believed but also with how they defended their claim that Jesus was God's messiah. Indeed, from Paul's undisputed letters, we meet a man who is extraordinarily intelligent and who shows a fondness for detail when attending to or constructing an argument. It is inconceivable that the author of these letters would so zealously have persecuted the church without a thorough knowledge of its message. Moreover, Paul acknowledges elsewhere having received certain core tenets - that, for instance, "Christ died for our sins ... was buried ... and was raised on the third day" (1 Cor 15:3-4) - from a common apostolic tradition.

Clearly, then, Paul's claim to have received the entirety of his gospel from the risen Jesus is overstated, and probably stems in part from a desire to boost his apostolic authority among certain Galatian Christians who had recently embraced a version of the gospel quite different from his own. It is reasonable to assume that Paul received confirmation of the

As disconcerting as this might be for some Christians, at the heart of Paul's gospel is a human sacrifice that simultaneously pacifies God's wrath and satisfies his requirement that sin be punished.

9 Some understanding of Jewish atonement rites would seem necessary to make sense of Paul's claim that Jesus' death 'declares innocent' and therefore reconciles people to God (Rom 5:1).

10 If we render the phrase as an objective genitive, Paul receives a 'revelation of Jesus Christ,' or a vision that may or may not have been accompanied by audible or didactic content ( 1 Cor 9:1;15:8). However, if we take it as a subjective genitive, Paul receives a 'revelation from Jesus Christ,' which must include at least some propositional content. Below, I suggest that the specifics of his gospel emerged over time, probably as a result of reflection on the Jewish scriptures as well as certain insights that he had while preaching and planting congregations. I see no need to attribute didactic content to his first vision, and therefore prefer to render the phrase as an objective genitive. It is certainly reasonable to assume that Paul, upon seeing Jesus, felt an inner conviction that the Christian kerygma was true, and even an obligation to go out and proclaim the message, but the evidence from his undisputed letters doesn't really demand more than this. 
truth of the church's kerygma during his initial vision of the risen Jesus (1 Cor 9:1;15:8), ${ }^{11}$ but the insights that he felt were unique to his gospel - say, that Gentiles need not be circumcised, adhere to Jewish dietary laws, or observe Jewish holidays - may have emerged in a much more mundane and gradual manner. They may, for instance, have arisen over a period of days or weeks while reflecting on the Jewish scriptures, or after he had to face the hard reality that the overwhelming majority of Gentiles simply weren't going to have anything to do with the gospel if (strict) Torah observance were to be required. As Rodney Stark suggests, many religious visionaries probably stumble upon a revolutionary insight and, unable to believe that they themselves could be its source, only later attribute it to a divine figure or sacred realm. ${ }^{12}$ Stark proposes that this may have been the case with Muhammad, who need not been seen as fraudulent or disposed to hallucinations, but who genuinely felt that his most important intuitions came 'from beyond,' and that he himself an unlettered commoner - wasn't possibly capable of the kinds of startling theological and ethical innovations he eventually propounded. ${ }^{13}$ Paul's case may be similar: following an initial vision of Jesus, which convinced him of the truth of the kerygma and awakened a strong desire to go out and tell others about it, he slowly began to modify apostolic tradition (with which he was well acquainted) in light of his own reading of the Jewish scriptures and his experiences as a travelling evangelist. Paul may very well have had good reason to believe that these incremental modifications were inspired by 'the Lord' as well.

Even if, as I suspect, Paul merely 'saw' Jesus initially (1 Cor 9:1;15:8) - just as, say, relatives of a recently deceased family member sometimes report 'seeing' their loved one when waking from or trailing off to sleep - and later arrived at the specifics of his gospel in a much more prosaic and incremental way, ${ }^{14}$ he nevertheless claims that his entire gospel was divinely revealed, and the logic of revelation dictates that its recipients endorse it not because it seems likely to be true or might benefit us in some significant way, but rather because of where or who it comes from. Put differently, religious adherents exempt divine revelation from ordinary standards of critical inquiry because of who the revealer is. ${ }^{15}$

Of course, just because $\mathrm{S}$ claims that $p$, it doesn't follow that $p$ is true. Indeed, even Paul's God is not always reliable: he deliberately deceives or withholds important information not only from those like Exodus's unnamed pharaoh who pose a threat to the Israelites' well-being (Exod 1-15) but from highly esteemed figures such as David, Job, and Abraham as well. ${ }^{16}$ If he deceived even them, it is at least conceivable that he may also have misled Paul when he 'revealed his son in [him]. ${ }^{17}$ Moreover, in the days immediately

11 See, e.g. Michael Winger, 'Tradition, Revelation and Gospel: A Study in Galatians,' Journal for the Study of the New Testament 53, 1994:78.

12 'A Theory of Revelations,' Journal for the Scientific Study of Religion 36.2, 1999:292-295.

13 Ibid. pp. 293-294.

14 I thank my colleague Tom Blanton for this important insight. Every semester, I teach a survey course on the world's major religions, and, in view of the heavy didactic content claimed by other prophets we discuss in class (such as Zarathustra, Muhammad, or Joseph Smith), for many years I unreflectively put Paul in a similar category. The evidence from his undisputed letters, however, certainly doesn't require us to attribute didactic content to his early vision(s).

15 See John H Whittaker, 'The logic of authoritative revelations,' International Journal of Philosophy of Religion 68, 2010:167-181.

16 See, e.g., 1 Sam 24:1-17; Job 1-2;38-41; Gen 22:1.

17 In the New Testament, too, it is not uncommon for God to conceal vital, potentially salvific information, presumably because he doesn't want certain people to participate in his coming kingdom. In the synoptic Gospels, for instance, Jesus is said to speak in parables for the purpose of concealing God's 'mystery' from outsiders, lest they turn from the error of their ways and be forgiven (see esp. Mark 4:11-12, 33-34; Matt 13:10-17; Luke 8:9-10). In an effort to explain widespread rejection of the gospel among fellow Jews, Paul 
after his first vision, Paul was very poorly positioned to assess Jesus' character or credibility as a witness to God's plan of salvation. Trust is best extended to others only once a relational history has been established, especially when so much is at stake - here, the means by which both Jews and Gentiles might obtain eternal life. Indeed, many other prophets in the Abrahamic traditions initially seem to have wrestled with whether they had in fact spoken with a divine being or whether this visitor from another world should be trusted (Muhammad is an excellent example).

But Paul appears not to consider the possibilities of deception or a simple error on his part. Not only is he convinced beyond any shadow of doubt in the veridicality of his vision of Jesus, but he also proceeds on the assumption that Jesus is a fully trustworthy witness and guide. In fact, for him, that $p$ (in this case, the gospel) was revealed by none other than God's son automatically authenticates its truthfulness: there is simply no need, in this particular instance, to justify $p$ rationally. Moreover, Paul seems to hold that ordinary human ratiocination, such as one might have found among other first century orators and philosophers, is an inherently insecure basis in which to place one's confidence. It also yields far too wide an array of incommensurate results, most of which will prove unpersuasive to subsequent generations and gradually fade from human consciousness. It is far better, says Paul, to place one's trust in the eternal truth of the divinely revealed gospel, which is validated not through 'persuasive words' or a sophisticated rhetorical demonstration, but through "a demonstration of Spirit and power" (1 Cor 2:4-5). ${ }^{18}$ Rhetorical flair, in fact, empties the gospel of its power, which is apparently why Paul elected to come to the Corinthians preaching not "in lofty words or wisdom" but only "Jesus Christ, and him crucified" (1 Cor $1: 17 ; 2: 1-2)$.

\section{Paul's Prospective Converts: Epistemic and Ethical Concerns}

Because of his unique and vivid encounter with the risen Jesus, Paul has the luxury of truly believing both that Jesus is no longer dead and that the Christian proclamation accurately conveys God's will. That is to say, because Paul actually 'saw' Jesus and attributed the content of his gospel to a revelation from him (even if the full disclosure emerged only gradually over weeks or months during prayer or reflection), it appears that he comes to believe involuntarily, much as we might come to believe that it is our spouse who now sits across from us at the dinner table or that objects fall when you drop them. For Paul, the risen Jesus is both unimpeachably real and fully reliable, which means that he is able to form and maintain his beliefs about his resurrection and the kerygma grounded in this seminal event (1 Cor 15:12-19) ${ }^{19}$ without any effort at all. In effect, Paul can't help but

suggests that God deliberately hardened the hearts of those who refused to convert (Rom 11:7-10). And the pseudonymous author of 2 Thessalonians states that God will one day send out a 'powerful delusion' so that the majority of our species will 'believe what is false' (2:11-12). The above passages seem to reflect an attempt by early Christians to explain why so many remained unpersuaded by the gospel, but it should at least be clear that Christians, too, had no trouble at all believing that God could - and did - deliberately mislead people.

18 Apodeixsis (rendered 'demonstration' above) was a common rhetorical term at the time, but here Paul applies it to the Spirit's work in the Christian community. If one is looking for a truly convincing 'demonstration,' argues Paul, look not to those generated by human philosophers and rhetoricians (who are fallible and whose opinions are constantly shifting), but to the fully reliable 'demonstration' provided by God's Spirit.

19 The resurrection is absolutely central for Paul. In fact, the truth of the kerygma rests entirely upon this event having really taken place. If God didn't raise Jesus from the dead, says Paul, not only has 'our proclamation been in vain,' but 'your faith has been in vain ... [and] you are still in your sins' (15:14-17). 
believe: the truth of the Christian proclamation has elicited a deep inner conviction about which he has little choice.

His audiences, however, are not so advantageously positioned. Recipients of Paul's gospel, who have not had a personal 'revelation of Jesus Christ,' are asked to trust him - to take it on faith that he, in fact, is privy to a divine disclosure, and that he isn't mistaken about the origin or nature of his encounter with the risen Jesus. Unable to verify the truth of his claim independently, they have no choice but to accept his account and proceed 'as if,' hoping that the confidence Paul enjoys may arrive at a later date. ${ }^{20}$ So, in addition to being exempt from critical inquiry and rational justification, revelation mediated through a handful of human agents requires a rather robust act of will on believers' part as well - a willingness 'to trust the testifier,' as Rolfe King has aptly put it, ${ }^{21}$ and to 'walk by faith' (2 Cor 5:7).

Admittedly, Paul's communities will not remain completely reliant upon him, for he also believes that all Christians eventually receive a share of God's Spirit (1 Cor 12:4-13), which appears to play an important role in awakening and sustaining conviction in a message initially received on faith (1 Cor 12:3). The Spirit enables believers to receive the gospel not as 'foolishness' or as a 'stumbling block' but as 'wisdom from God' (1 Cor $1: 18-25 ; 2: 7)$. However, at no point does Paul suggest that believers can expect to receive independent disclosures of their own that reproduce the very same details about God's 'mystery' that he already has given them. Ordinary Christians must still trust, for instance, that Jesus' death nullifies the effects of sin, and that Gentiles need not fulfill basic ritual obligations prescribed by the Torah in order to be rescued from God's impending wrath (1 Thess 1: 9-10). The Spirit might offer some assurance that one is a child of God (Rom 8:1617), or it might enable one to affirm that 'Jesus is Lord' (1 Cor 12:3), but independent verification of the details of the gospel is not to be expected. For this, faith is still - and apparently always will be - necessary.

Because Paul suggests that he is the only witness to his 'revelation of Jesus Christ,' many in his audiences understandably may have doubted the veracity of his claims. Questions one might legitimately wish to ask Paul include: Did you merely 'see' Jesus, or did you receive some kind of audible communication as well? If so, what did his voice sound like? Did he speak slowly or quickly? Did he speak in Aramaic, Hebrew, or even in Greek? Or, did you receive a vague or inchoate insight while reading or reflecting that you later attributed to the risen Jesus and rendered into propositional language? If the latter, how can you be certain that this insight originated from a transcendent source and not from within your own mind ? $^{22}$ Also, since there is no precedent for this divine 'mystery,' and

20 For a helpful summary of recent discussions on the differences between belief and acceptance, see Pascal Engel, 'Introduction: The Varieties of Belief and Acceptance,' in Believing and Accepting, ed. Pascal Engel. Boston: Kluwer Academic, 2000, especially pp. 1-16.

21 'Divine Revelation,' p. 500. See also his book Obstacles to Divine Revelation: God and the Reorientation of Human Reason. New York: Continuum, 2008.

22 John Whittaker argues that although questions such as these naturally may arise when someone claims to have received a propositional revelation, they nevertheless miss the point: "My sense is that such questions are impertinent; and they are impertinent because they miss the point of utilizing such imagery, which is not to fill in all the details regarding what it is supposed to be like to receive a revelation, but simply to repeat the authoritative status of the prophet's claim by dressing it up in human analogies". "The logic of authoritative revelations," p. 169. However, it seems to me that someone who claims to have received an audible revelation of a propositional nature from a personal deity really ought to be able to answer all such questions clearly and without hesitation. If, for instance, she were to stumble over the first four questions, or take too long to formulate a response, it would be reasonable to infer that she received some kind of vague insight rather than 
since it is incompatible with so many other past and contemporaneous revelations, why should we believe you? How are we to know for sure that your revelation is entirely true and that those from, say, ancient Canaanite or modern-day Roman prophets miss the mark?

In addition to these epistemological questions, there are equally pressing ethical ones. Recipients of Paul's message may wonder: Why does God not disclose the contents of his plan of salvation directly to us as well? Why does he speak to so few of you (men) and then require the rest of us simply to trust you? Why does God not arrange things so that everyone on the planet can arrive at genuine belief involuntarily, much in the same way we arrive at belief in the existence of fig trees or that animal sacrifices are offered up daily by priests at the temple in Jerusalem? Why make a virtue of accepting propositions in the absence of empirical evidence that might easily be cross-checked ? $^{23}$ Why not make the evidence plain to all so that we can't help but believe? Not only would many more people be saved, but we also would be evaluated on what we choose to do (or not do) with a body of common knowledge rather than on whether or not certain beliefs happen to take root in our minds.

Of course, Paul's appeal to revelation via a handful of divinely chosen intermediaries is hardly unique in the New Testament. Jesus, for instance, routinely appeals not to the plausibility or reasonability of his message but to having unparalleled access to God's character and purposes. In the synoptic Gospels, his audiences are not invited to weigh the merits or consequences of the message, as a contemporary philosopher might have done. Rather, the people he encounters are asked to accept it both on his and his father's authority. Ultimately, for those who do join his movement, they will endorse the gospel because of where it comes from, not because it makes the best sense of the available evidence or offers the greatest potential among competing visions to foster human wellbeing. And, as is the nature with any divinely revealed 'mystery,' it cannot be inferred from an existing pool of common knowledge. We are entirely dependent upon God's initiative to know anything about it. Indeed, Jesus acknowledges that God has deliberately 'hidden' it from his own generation's 'wise and intelligent' (the ruling and religious elite) and elected rather to reveal it to 'infants' (disciples). But it's not only God's plan of salvation that remains inaccessible outside of revelation: the father himself can be known only by those "to whom the son chooses to reveal him." For all others, the true nature of the father remains concealed (Matt 11:25-27; Luke 10:21-22).

This emphasis upon a believer's duty to accept the message exclusively on the authority the revealer is echoed - even intensified - in the Gospel of John. In fact, if there is one point that the Gospel's author is at extraordinary pains to make, it is that Jesus is God's exclusive and trustworthy representative on Earth. Everything that Jesus says and does is a perfect reflection of the father's character and will. Moreover, as in the synoptic Gospels, one is entirely dependent upon God's initiative to know anything about him and his plan of

a direct audible communication. Stumbling over the first four questions, then, places the veridicality of the experience in serious doubt. If, in fact, some kind of audible communication accompanied a vision, these questions should present no trouble at all.

23 We generally don't view this kind of faith as desirable or virtuous in other spheres of life. Physicians today, for instance, generally must provide some empirical evidence that one has a disease before proceeding to treat it. Likewise, pharmaceutical companies have to demonstrate the efficacy and relative safety of a given drug before the FDA will make it available for purchase. And architects must show that a building will be structurally sound before moving forward with construction (see, e.g., Sam Harris, The End of Faith: Religion, Terror, and the Future of Reason. New York: Norton, 2004:66). Faith is not desirable in any of the above cases. Rather, empirical evidence is required, and for very good reasons. Why, then, does God demand faith when it comes to matters of such monumental existential importance? 
salvation. One must, for example, be 'drawn by the father' in order to see that it is Jesus alone who faithfully communicates God's nature and intentions (6:44,65; 14:6-9). Presumably, the father draws people by means of the Spirit, which chooses not to illumine everyone, but blows only 'as it wills' (3:8) - a claim that logically ought to (but does not) exonerate non-believers from finding John's message about Jesus unconvincing. In all of this, one is again asked 'to trust the testifier,' and without any expectation that the details of the gospel will - or even can - be verified independently. God's plan, as it is mediated by the Johannine Jesus, may seem strange, implausible, or, in some cases, even ethically unappealing, but as in Paul's letters, how one feels about this plan is entirely irrelevant. The adherent takes it on faith, chiefly because of where it comes from.

\section{Paul's Gospel and Contemporary Christian Faith}

If Paul's contemporaries, most of whom took for granted the existence of a densely populated transcendent realm, had good reason to question his claims, we (post)moderns face even greater epistemic and ethical challenges. For us, the existence of a sacred unseen realm is hardly an unproblematic feature of our noetic inheritance. The mere suggestion that a benevolent deity exists and created the universe has been rigorously contested since the Enlightenment. Very few of Paul's contemporaries would have raised a fuss over the notion that gods exist, create, communicate with human beings, and even intervene in our daily lives, both for good and for ill. None of this, however, is self-evident today. This is certainly the case for academics, but it's also true for a great many others who have chosen to subject traditional religious claims to critical inquiry. The bare assertion of the existence of a divine artificer or of some kind of impersonal 'ground of being' like brahman or tao may not prove especially troublesome, but that the divine has revealed to certain individuals a specific set of moral and ritual obligations required for salvation or liberation often does.

Even Richard Swinburne concedes that there are rather serious epistemological difficulties that come with placing so much trust in the private religious experiences of a handful of men who lived so long ago. One of the best reasons, he argues, for endorsing the Christian revelation over competing disclosures given to, say, Muhammad or Joseph Smith, is that it was accompanied by what he calls 'public miracles. ${ }^{24}$ In Paul's communities, these miracles would consist minimally of the Spirit's work through prophecy, healing, and possibly even glossolalia. In the absence of these regular 'demonstration[s] of Spirit and power' (1 Cor 2:5), faith must play a much greater role, as it does in most mainline Protestant, Roman Catholic and Orthodox communities today. The kinds of religious experiences frequently cited by members of mainline communities - a vague sense of divine power and/or benevolence while gazing upon a majestic landscape, for instance, or the sudden feeling that everything will work out for the best - can hardly be classified as

24 'Revelation,' in Routledge Encyclopedia of Philosophy Online, ed. E Craig. London: Routledge, 1998, retrieved 9/17/2013 from http:///www.rep.routledge.com/article/K089. He writes: "But in view of the conflicting revelations purportedly inspired by God to which 'inner conviction' has seemed to testify, and the danger of self-deception in such matters, it would be dangerous for those other than the prophet to rely too much on inner conviction to authenticate such detailed claims about God as a revelation purports to give. There is need for public miracles" (italics mine). See also his book Revelation: From Metaphor to Analogy, $2^{\text {nd }}$ ed. Oxford: Oxford University Press, 2007. Muhammad's proclamation, says Swinburne, was not accompanied by such miracles, which is a major reason why he considers the Christian scriptures to be superior to the Qur'an. For a rebuttal of Swinburne on this point, see Amir Dastmalchian, "Swinburne's View of the Islamic Revelation,” Journal of Shi'a Islamic Studies 1.4 2008:95-104. 
'demonstration[s] of Spirit and power' on par with prophecy, glossolalia, or healing. Moreover, mainline Christians typically report that these kinds of sensations or insights are relatively infrequent. ${ }^{25}$ More often than not, they find themselves referring back to a few memorable religious experiences from the past to help sustain their faith rather than to a 'demonstration of Spirit and power' that occurred, say, yesterday evening or at last week's worship service. Without the benefit of regular and convincing religious experiences, most mainline Christians therefore have little choice but 'to trust the testifier' and hope for the best.

In charismatic communities, however, it is believed that the Spirit works miracles all the time. In fact, many in 'Spirit-filled' churches report that the divine presence feels as real as just about anything else in the phenomenal world, so that a charismatic Christian might legitimately speak of belief - an inner conviction that arises and is sustained effortlessly in God and his Spirit rather than mere acceptance. ${ }^{26}$ Faith is still required to get the spiritual life off the ground, but recurrent experiences 'of Spirit and power' similar to those that purportedly occurred in Paul's communities greatly increase the likelihood that beliefs will arise passively rather than through an effort of will.

Of course, while charismatic Christians may feel a more lively connection with the divine, there is still the question of whether any of their experiences are actually veridical. Glossolalia may involve no more than acquiring competence in trance states and learning to mimic whatever (nonsensical) speech patterns are modeled by a given congregation's leaders and laity. ${ }^{27}$ Because prophecies are often so vague or embarrassingly mundane, rarely disclosing anything truly worthy of having come from a transcendent realm, a naturalistic explanation seems far more fitting. Indeed, as Evan Fales observes, prophecy, if it were routinely to be fulfilled, would seem to offer fairly strong evidence for the veridicality of mystical experience generally. Unfortunately, what we find is that the few prophets who do venture disclosures of some specificity receive only a few lucky hits amid a torrent of misses. Their overall record, he rightly concludes, "is one of failure." 28 And claims of divine healing too often are rather easily disconfirmed upon examination ${ }^{29}$ or simply incapable of being verified because no visible change to a person's body is apparent. At faith healing services, never do we see anything worthy of an all-powerful and insuperably intelligent creator, such as the spontaneous regeneration of limbs, spinal cords, or severely burned skin.

25 For a helpful taxonomy of reports from a group of mainline Protestants and Roman Catholics that also includes several excellent examples, see Rodney Stark, "A Taxonomy of Religious Experience," Journal for the Scientific Study of Religion 5.1, 1965:97-116.

26 John Hick suggests that this may have been the case with many of the prophets whose oracles are preserved in the Hebrew Bible: "[T]heir awareness of God was so vivid that ... they could no more help believing in the reality of God than in the reality of the material world... God was known to the prophets ... as a dynamic will interacting with their own wills; a sheerly given personal reality". Qtd. Paul Badham, "The Authority of Religious Experience,” pp. 13-14.

27 See Felicitas Goodman's 'Glossolalia' in The Encyclopedia of Religion, ed. Lindsay Jones. Detroit: Macmillan Reference, 2005:3504-3507, as well as her book Speaking in Tongues: A Cross-Cultural Study of Glossolalia. Chicago: University of Chicago Press, 1972. See also Nicholas Spanos, Wendy Cross, Mark Lepage, and Marjorie Coristine, 'Glossolalia as Learned Behavior: An Experimental Demonstration,' Journal of Abnormal Psychology 95.1, 1986:21-23; William Samarin, 'Variation and variables in religious glossolalia,' Language in Society 1.1, 1972:121-130.

28 'Do Mystics See God?', in Contemporary Debates in Philosophy of Religion, eds. Michael Peterson and Raymond van Arragon. Malden: Blackwell, 2004, especially pp. 156-158.

29 For a delightfully entertaining and informative behind-the-scenes look at faith healing, see James Randi's The Faith Healers. Amherst, NY: Prometheus, 1989. 
The objections to revelation in general are numerous and widely known, so I certainly won't rehash them here. For me, the four most important of these with regard to Paul's revelation in particular are: 1) there is no way to establish its veridicality, in part because the apostle himself is (presumably) its only witness, ${ }^{30} 2$ ) it conflicts with countless other divine disclosures reported through the ages, including many within the Jewish tradition itself; 3) it requires allegiance to a deity whose plan of salvation is morally problematic at best; and 4) it too often demands that religious adherents table critical inquiry and proceed on faith.

I tend to side with William James on the matter of whether or not mystical experiences such as Paul's may be employed to justify religious beliefs: while they may be used by those who've had them in forming beliefs about a sacred order, he says, those who haven't had them are under no obligation whatsoever to accept their testimony as veridical. However, I see no viable defense for why an outsider to Paul's Jewish-Christian tradition should endorse a revelation from him over one from, say, Zarathustra, Muhammad or Joseph Smith. Importantly, their disclosures are not compatible, yet all three prophets appear to have exhibited the same level of conviction that Paul does. When disclosures differ so radically, and their messengers exhibit a similar level of conviction, by what criteria is an outsider to assess which of them are true and which are not? ${ }^{31}$ And, even if Paul happens to be the bearer of a true revelation, it seems to me that the morally decent thing to do is to decline relations with his God, who apparently has no problem creating the vast majority of our species for the sole purpose of being destroyed while designating a mere handful "for glory" (Rom 9:19-24). Finally, encouraging adherents to accept a past divine disclosure on faith fosters the kinds of mental habits that are not going to benefit us in the long run. Our beliefs, I assume, aim at truth and guide much of what we do and say, and because this is so, they ought to be proportioned to the best available evidence rather than accepted on the purported authority of a revealer. Our religious beliefs are not merely a private matter, as many Christians still seem to believe. Because they often have profound social consequences, they ought to be formed in a responsible manner that is attentive both to evidence and to principles of sound reasoning. The logic of revelation necessarily fosters what WK Clifford long ago called "the credulous character," which, if it should be found among too many of us, will not serve our species well. ${ }^{32}$ Patient, critical inquiry has a far better shot at generating beliefs consonant with reality than simply taking on faith a list of unverifiable claims revealed through one man's - or a few men's - mystical experiences.

And yet, according to Paul, this is precisely what is required. Kevin Vanhoozer, I think, is right on target when he says that Christians believe what they do about God and

30 Although the narrator of Acts does suggest that, during Paul's first encounter with Jesus, his travelling companions were likely aware that he had encountered some kind of supernatural presence, Paul himself never indicates that this was the case (biblical scholars today generally defer to Paul's letters rather than to the author of Acts, who is writing at least two decades after Paul's death). Even if we were to assume that the author of Acts is correct in saying that others were present during the apostle's initial vision, at no point is it made clear that they had any idea what was being communicated.

31 Other than, of course, Swinburne's 'public miracles' criterion. To be entirely candid here, because I generally accept Hume's classic arguments against miracles in general (whether Jewish, Christian, or otherwise), Swinburne's defense has no chance of persuading me. I see no good reason to believe that Jewish or Christian miracles are more likely to have occurred than, say, miracles recorded by Hindus or Buddhists.

32 'The Ethics of Belief,' in Philosophical Inquiry: Classic and Contemporary Readings, ed. Jonathan Adler and Catherine Elgin, Indianapolis: Hackett, 2007:789. 
his purposes "not because they discovered it but because they were told." "33 "[W]hat makes thought distinctly Christian," he says, "is its rootedness in apostolic testimony," which bears witness to a transcendent truth that "human beings could not even in principle find out." 34 Whether or not 'apostolic testimony' such as Paul's makes any sense or proves ethically advantageous are irrelevant. It ought to be accepted solely because of where it comes from. Moreover, as many philosophers have observed, natural theology unaided by special revelation of the sort Paul provides will at best yield a bland artificer kindly disposed toward what he has made. ${ }^{35}$ Anything more - moral codes or a path to salvation, for instance - will have to come by way of revelation. As Mortimer Adler has said, while reason may indeed lead one to affirm the likelihood that a creator of some kind exists, reason alone is not able to show that this creator is both 'just and merciful' and actually cares for the welfare of sentient beings. "The God of the philosophers," he observes, "is not a God to be loved, worshiped or prayed to. ${ }^{, 37}$ For a form of theism with any meaningful content upon which to direct one's life, revelation will be required. Blaise Pascal would agree wholeheartedly: "All those who seek God apart from Christ, and who go no further than nature, ... find no light to satisfy them, ... thus falling into either atheism or deism, two things almost equally abhorrent to Christianity." 38

\section{Concluding Reflections}

A mainline Christian, then, for whom Paul remains an authority but who does not experience a regular 'demonstration of Spirit and power' is in the rather unfortunate epistemic position of having 'to trust the testifier' - a testifier whom none of us have had the good pleasure of meeting. Ordinarily, we trust witnesses we know have proven reliable in the past or possess the requisite credentials to speak to a given issue. But with Paul, we have no past relationship upon which to establish reliability, and it's not at all clear why we should see him as having credentials superior to Zarathustra, Muhammad or Joseph Smith when addressing a sacred order. In fact, because he so badly misjudges the timing of Jesus' parousia - information, importantly, that he attributes to a direct revelation from the risen Jesus (1 Thess 4:13-18) - we may rightly wonder whether we should trust any other divine disclosures from him.

So, for the overwhelming majority of Christians, it must come down to faith, not to the reasonableness, plausibility, or persuasiveness of the gospel. When Paul tells the Corinthian Christians that his 'message about the cross' is received as just plain 'foolishness' or as a 'stumbling block' by anyone not already endowed with God's Spirit, Paul candidly acknowledges as much (1 Cor 1:18-25). Today, in an age that (rightly) demands evidence and good reasons for our models of reality, such an admission necessarily comes with some

33 'Theology and the condition of postmodernity: a report on knowledge (of God), in The Cambridge Companion to Postmodern Theology, ed. Kevin Vanhoozer. Cambridge: Cambridge University Press, 2003:24.

34 'Pilgrim's Digress: Christian Thinking on and about the Postmodern Way,' in Christianity and the Postmodern Turn: Six Views, ed. Myron Penner. Grand Rapids: Brazos Press, 2005:95.

35 I am being as charitable as I can here in granting that God is 'kindly disposed,' for too many of us, the variety and magnitude of both natural and moral evil would strongly suggest otherwise.

36 'A Philosopher's Religious Faith,' in Philosophers Who Believe: The Spiritual Journeys of 11 Leading Thinkers, ed. Kelly James Clark. Downers Grove: IVP, 1993:215.

37 Ibid.

38 Pensées 449, qtd. Andrew Moore, 'Should Christians do Natural Theology?' Scottish Journal of Theology 63.2, 2010:145. 
epistemic embarrassment. This is, as I've argued, the price that any Christian who is honest about the revelatory foundations of her tradition must pay. The gospel cannot be inferred from a common pool of knowledge or from principles of logic, so without the benefit of divine revelation and a willingness on our part to trust ancient witnesses, we are at best left with a vacuous theism that offers adherents no clear sense of who God is, no moral guidance, and no path to salvation. Paul was courageous enough to admit that the 'foolishness' of the gospel must be received in faith, backed perhaps to some small degree by a 'demonstration of Spirit' for those lucky few to whom God's Spirit regularly makes its presence and power known. Maybe this puts charismatic Christians in a slightly more advantageous epistemic position, ${ }^{39}$ but mainline believers are left with little to go on but the credibility of a few ancient (male) witnesses whom they've never met and whose characters they are poorly positioned to assess. That hardly inspires confidence, and the beliefs generated from simply trusting these witnesses certainly cannot pass as knowledge today.

39 Although, as I noted above, even with the assistance of the Spirit, Christians are not to expect independent verification of the details of the gospel. 